DOI https://doi.org/10.18551/rjoas.2018-12.18

\title{
THE IMPACT OF BUSINESS PROJECT TARGET ON STUDENTS' BEHAVIOR: A PHENOMENOLOGY STUDY IN ACCOUNTING DEPARTMENT OF CIPUTRA UNIVERSITY
}

\author{
Putra Teofilus Pratama \\ Department of Accounting, Faculty of Economics and Business, \\ University of Airlangga, Surabaya, Indonesia \\ E-mail: teofiluspratama@gmail.com
}

\begin{abstract}
The development of entrepreneurship education is growing in Indonesia, especially in universities. One method used in entrepreneurship education is experiential based learning, which is one method by pioneering real business projects by students. One important step in a business project is setting targets. The purpose of this study is to uncover more deeply the impact of business project targets on student behavior of the Ciputra University Accounting Department. This study uses a qualitative approach with phenomenological methods. Data was collected using in-depth interviews and unstructured observations. The results of this study are targets that have a positive impact on behavior and mindset, despite the many obstacles faced by informants. Targets are not the main tools to motivate informants, but targets are the boundaries that must be achieved. The main tool that can motivate informants is the maximum guidance process.
\end{abstract}

\section{KEY WORDS}

Experiential based learning, accounting behavior, entrepreneurship education, escalation of commitment, budgetary slack, hurdle rate.

Entrepreneurship education at Ciputra University uses an experiential based learning approach. One method used is to require students to form real business projects starting from the first semester. Experiential based learning is a method that aims to provide a real and guided experience so that it can contribute to society. Through this approach, students will learn in an active process that builds the building rather than merely acquiring knowledge. In this case students will be active learning, involved in authentic and situational learning activities, interesting and challenging learning activities. This approach makes the function of the lecturer as a facilitator and is able to provide assistance in the form of scafolding that is needed by students in the educational process (Pribadi, 2009).

At the beginning of learning, students are trained to see opportunities around the campus environment, then equipped with the basics of entrepreneurship, and continued to establish businesses, both individuals and groups. The students also began to be trained to make business plans. After making a business plan at the end of the first semester, at the beginning of the second semester to the beginning of the sixth semester students attend a business plan session to determine the target of their business projects.

However, some Ciputra University Accounting students felt anxious if the target could not be achieved, even though the target was only one of the elements of the assessment that weighed $20 \%$. Some students assume that the target of a business project is too high, making them feel insecure and pessimistic that they can reach the target so that it influences the behavior of students in running business projects. The following is a student expression regarding the target:

"...in fact the impact that occurs because students feel the target is too high and impossible so students feel free to pursue the target..." (Informant 1)

"Too busy with college, while the project target is too high..." (Informant 2)

Students who are not motivated may take wrong or distorted decisions. This concept of action is studied in the field of accounting behavior which is the study of accountant behavior or non-accountant behavior when they are influenced by accounting and reporting functions 
(Radianto, 2015; 1). One aspect that often has a relationship between behavior and targets is budgetary slack or budget security, which is a practice that managers do deliberately enter a greater amount of expenditure (a smaller amount of income) into the budget than they actually believe will happen (Blocher, 2010: 395). In the case of student business it can be illustrated that the budget is like a target that must be met. This can occur in student business projects in this case how students secure their business targets so that they can achieve these targets.

Students can commit behavioral irregularities, namely manipulating business project reports even though they have not reached the target set. If this happens, students will run a project that loses continuously to maintain the business project until the end of the semester. This can be called an escalation of commitment (Radianto, 2015: 22). Students can avoid the escalation of commitment and manipulate business project reports, if from the beginning students calculate the hurdle rate target, which is the target rate of return implied on capital expenditure activities. Using a hurdle rate, the management can determine the economic limits of the project being run (Radianto, 2015).

In the case of the Accounting Department at Ciputra University, the actual action of escalation of commitment can be reduced by calculating the rate of return (hurdle rate), which uses the concept of participatory budgeting. If the business that is run its rate of return is below the predetermined target, the student business project experiences a loss, and vice versa if the business that is run its rate of return is above the target set, then the business project carried out is profitable. Based on this background, the problem of this research is how to impact the target on business projects on student behavior. Therefore the purpose of this research is to reveal more about the impact of the business project target on the behavior of students of the Accounting Department at Ciputra University.

Researchers will investigate in depth how students experience seeing phenomena that occur in real cases on the ground, so this study uses phenomenological methods. Through this method the writer will be able to understand and interpret what phenomena experienced by the research subject, so that the objectives of this research can be achieved.

\section{THEORETICAL REVIEW}

The theory that is relevant to this research is accounting behavior which includes escalation of commitment, budgetary slack, participation budget, and hurdle rate. Behavioral accounting is a subdiscipline of accounting science that involves aspects of human behavior related to the process of economic decision making (Lubis, 2010: 12). According to Radianto (2015), behavioral accounting includes several things.

First, judgment and decision making of the auditor and accountant. Second, the influence of accounting functions (such as budgetary participation, information system characteristics) and audit functions on the behavior of employees, managers, investors, and third taxpayers, the effect of the output of accounting and audit functions, namely accounting information on user consideration and decision making.

Escalation of commitment is defined as a phenomenon that explains that a person decides to increase / increase his investment, even though new evidence explains that the decision made is wrong. The investment can be in the form of money, time, effort / energy (Bambang et al. 2011). Radianto (2015) argues that the escalation of commitment is a commitment of decision makers to continue and expand their initial commitment to investment projects that are not profitable. This means that someone continues to run investments that can be in the form of business even if they continue to experience losses.

Budgetary slack or budget security, is a practice that managers intentionally enter a greater amount of expenditure (a smaller amount of income) into the budget than they really believe will occur (Blocher, 2010: 395). Participatory budgeting is an approach that involves everyone in budget formation, from the lowest level employees to the managers of organizations / companies. Participatory budgeting runs effectively, if the manager is actively involved. Furthermore, top management must be aware of deviant budgets, and encourage 
budget projections to be accurate. Managers must act as mediators when disagreements occur in the budget preparation process (Blocher, 2010: 395).

The rate of return is also called a hurdle rate. The Hurdle rate is the target rate of return that is implied on capital expenditure activities. Through the hurdle rate, management can determine the economic limit of the project being run. Hurdle rate is a powerful tool for evaluating investment decisions as well as a powerful tool for controlling company investment (Radianto, 2015: 45).

\section{METHODS OF RESEARCH}

Based on the purpose of the research, it is to reveal more about the impact of the target of the business project on the behavior of Ciputra University Accounting students. So the researcher uses a qualitative approach to get more in-depth data, a data that contains meaning. Qualitative research is a research method used to examine the condition of natural objects, where researchers are a key instrument, data collection techniques are carried out jointly, data analysis is inductive, and research results emphasize the meaning rather than generalization (Sugiyono, 2014: 1).

This study uses phenomenological methods. Phenomenology is the study of what appears to be, or the knowledge of visible behaviors; something that appears in our consciousness. The phenomenology method looks closely at individual interpretations of its experiences. This study seeks to understand the meaning of an experience from the perspective of participants (Sugiyono, 2014, Sonny, 2013: 213).

Sampling in this study using purposive sampling, meaning that the researcher determines the informant who is considered to know about the research problem so that it will facilitate the writer to explore the situation under study (Sugiyono, 2014). The subject of this research is Ciputra University Accounting students who run a business project. The selection of subjects in this study is based on the consideration that the Accounting Department has compulsory business project subjects in each semester, so that all accounting students must carry out business projects. Researchers used six informants as informants, the criteria of informants in this study were Ciputra University accounting 2013 students and 2013 business projects, business projects successfully achieved targets and business projects did not reach the target.

There are several methods used by the author in collecting qualitative data on the subject under study. First is interviews, researchers use semi-structured interview methods that are included in the in-dept interview category (Sugiyono, 2014). The purpose of this type of interview is to find the problem more openly, where the interviewee is asked for opinions, and his ideas. This interview is open, meaning that the informant knows the presence of the interviewer as a researcher who is in charge of conducting interviews at the research location (Bungin, 2011). Next is observation. The author uses passive participation observation in data retrieval, meaning that the author observes the informant, but the author is not involved in informant activities (Sugiyono, 2014; 66).

Emzir (2010: 85) provides a definition of data analysis is a systematic process of searching and regulating transcripts of interviews, field notes, and other materials that have been collected to improve the author's understanding of the material.

In qualitative research, validity and reliability are also called the validity of the data, the validity of the data in this study using member check. According to Sugiyono (2014) member check is the process of checking data obtained by researchers to data providers. The purpose of member check is to find out how far the data obtained is in accordance with what is given by the data provider.

If the data found agreed by the data giver means that the data is valid, so that it is more credible / trusted, but if the data found by the researcher with various interpretations is not agreed upon by the data giver, and if the difference is sharp, the researcher must change the findings, and must adjust to what is given by the data provider. So the purpose of the member check is so that the information obtained and will be used in writing the report in accordance with what is meant by the data source or informant. Member check execution 
can be done after one period of data collection is complete, or after obtaining a finding, or conclusion.

\section{RESULTS OF STUDY}

Ciputra University Accounting Department uses an integrated accounting teaching system (creative, innovative, and Holistic Synergy) and uses Experiential Based Learning to provide Entrepreneurial Accounting Projects. Students are also given the opportunity to apprentice in the company owned by the Ciputra Group, but it does not rule out the possibility of students looking for another company where they can take part in the apprentice program. Extensive Accounting Training is given to improve skills and competencies, students. Through these programs, students are expected to have a balance in "Street Smart" and "Smart Book", theory and practice, and "Hard Skill" and "Soft Skill". (source: www.uc.ac.id, 2015)

Data Analysis. Interviews were conducted on six student business projects in different fields. The targets obtained in each business project are also different, ranging from targets on product sales, getting clients, developing social media accounts, finding a consignment place, to participating in the exhibition. The results of observations conducted by the researcher shows that there are various kinds of expressions and emotions that appear in the informant, such as enthusiasm, confidence, doubt, sadness, anxiety, satisfaction, and a sense of pride.

The first informant was a 2013 student business project, the business was engaged in the trading of the remaining children's export clothing. The informant targets to sell 1,800 pcs / month and expand the market to three islands in Indonesia. The informant realizes that if the target of the business project is reached then it can meet the needs of life, but until now the informant has never reached the target.

"Yes, 1,800 a month, but we never achieved it until now..."

"...if for example we really want to do what we want, for example, we really want to make money, fulfill our daily needs, that's 1,800 a month, it must be..."

According to informants, there are quite a number of obstacles experienced during running a business project. An internet network that is less supportive is one of the factors that hinder online sales, the lack of relationships in terms of suppliers and customers is another inhibiting factor. The number of competitors who sell similar products is also an inhibiting factor because the products of informants and competitors have almost no difference, competition only occurs at the selling price.

The informant has done various ways so that the target can be achieved. Informants have made sales to various places, such as participating in exhibitions, selling on car free days, Instagram, Tokopedia (e-commerce), and offering products to several pediatricians to invite consignment cooperation and make promos to attract customers.

According to the informant, to achieve the target of the business project, a good focus is needed, while the informants have difficulty dividing their time between running a project and doing lecture assignments, the impact is that the informants feel that they are not optimal in carrying out college assignments.

"...for example, assignments from other lecturers, other courses are not completed because of the focus on the project target. We still finish it, but often the results are even worse..."

A lot of ways have been done by the informant but the target cannot yet be achieved. This makes the informant feel ashamed because the target is always the same but has never been achieved. The shame of having never reached the target made the informant eager to prove that she was capable.

The informant feels that the target of a business project has an impact on his life, both in behavior and thinking. According to the informant, during running a business project she became a person who was more resilient, not lazy, wanting to continue to grow, and able to place a position according to the person she was talking to. In addition, the informant felt that 
she understood the cycle / process of establishing and running a business even though it was still little.

The second informant is a 2014 student business project in the field of fashion with a sales target of five dozen per month, participating in exhibitions, and improving the marketing system. The informant feels confident that he can reach the target. To reach the target informants have prepared a number of strategies, such as this semester will focus on online sales by improving social media accounts, entering products in several e-commerce, and innovating to find product characteristics.

"Sure because many costumers say our products are good..."

"...because this semester will be devoted to marketing..."

"Now we are focusing on selling and innovating because we are also required to innovate by making products that have their characteristics..."

In the second semester, the informants failed to reach the target, according to the informants the obstacles that occur due to lack of time to sell, because most of the time in the second semester is used to improve the product. Another obstacle faced by informants in achieving targets is the difficulty of dividing time between running a business project, organizational activities and doing college assignments.

The informant also felt that he had a lot of targets, so when he saw the target list, he felt tired. The informant also said that the target given by the facilitator was sometimes difficult to do, for example the facilitator gave a target to return to the exhibition called Inacraft, according to the informant it was not possible because the exhibition could only be followed once.

"...the target is very much, because we have to set a schedule that is quite solid. Angel and I entered the organization so our time was wasted again... "

"The negative is that the target doesn't make sense, so it's not done but it's tired..."

"...for example Inacraft sponsored by Ciputra University, we cannot join the second time, even if we want to enter we must join the Inacraft membership and there is a monthly fee and the guarantee fee can be up to 15 million rupiah, we mean it is very maybe we can go in there..."

The informant argued that the target had a positive impact, with the target infoman could get to know many people, motivated to prove able to achieve the target, and change attitudes for the better.

"If it is positive, we are encouraged to be given a chance that in the future we have more progress..."

"...When I enter here I add insight, can interact, speak well to people..."

The third informant is a 2014 student business project in the field of educational entertainment that produces and sells board games. In this semester informants have a target of selling products to penetrate the national market. At first the informant felt that the target was difficult to achieve, but the person concerned was aware that being able to achieve the target needed to be effortless and patient. The efforts made by the informants were to continue to offer their products to a number of schools that were the target market for informants. Every week, informants and group members often hold meetings to evaluate and create new strategies.

"First, it is indeed difficult because of business problems and we are targeting 50 sales and from there we learn that all of them need a struggle, if we don't try it can't be achieved..."

"The sales strategy, for example this week, is not achieved next week, how rich will it be, so every week for evaluating other than directing the sales to the product as well as the consumer's weakness..."

The main obstacle that until now was faced by informants was the difficulty of dividing time between running a business project and doing college assignments. To overcome this, usually the informant and group members share tasks. Besides time, product design is also an obstacle for informants. The informant felt that during the business project many positive changes had occurred. With the target, the informant becomes motivated to move forward. 
"For the time because of the many assignments we were confused which one was first... the design aspect was mostly complained because the consumers wanted a lot, finally we tried sharing it together and until now there hasn't been..."

"I have a friend whose members stutter so that they can't speak in public and even underestimate something but since yesterday we took part in the competition and that person wants to be forced to talk in the front has finally changed and the stutter disappears and it's amazing for us..."

The fourth informant is a 2013 student business project in the field of website creation and management services that have the target of getting ten clients to advertise on the website of the informant concerned. Slightly different from the previous informant, this time the informant felt unmotivated when running a business project, even though the informant claimed that the business he lived in was his passion. From the information obtained by the author, the informant felt that the process being undertaken did not lead to the target, so the informant felt in vain with the existence of the target.

"I was immediately given a target of 10 ads a semester, well, it was actually rather difficult at first... but given the target, yes it did help, but now for example lecturers only give a target and there is no help for what we are told to think about. It's the target, we are the ones who love, you know, it's up to you, what do you want to do, well, but once we do what we want instead to be scolded..."

Informants argued that given the target in question became depressed and not free in running a business project because the informant had to divide the time between running the project and doing the assignments. Meanwhile, the informant considered the facilitator to be less helpful in guiding the relevant business project so that the weekly target given by the facilitator was not in line with the one semester target.

"...the tutor didn't help me at all... Tutor Tirta only said that in two weeks it should be done so the point must be already there, just like that, so it was finished last week, I still haven't confirmed it, it hasn't been confirmed yet yes, the ebook party, the point is that it hasn't been answered until now, it will run out eh last week I said like that, then Mrs. Tirta means talking, if you can, next week, yes, like that, actually my main target isn't actually, the main target is ad, how come it suddenly becomes the ebook's focus..."

Although in the previous semester the informants managed to reach $80 \%$ of the target, but the informants still thought it was difficult to reach the target. Constraints faced by informants are owned by the website is relatively new so it is not widely known. In addition, the informant felt confused to set priorities in running a business project that caused informants to work only on their own.

The fifth informant is a 2014 business class student project in fashion that has a target of selling 150 pcs / semester and developing a social media account. Following is the fifth informant's statement:

"... if the production is not targeted, only the target is selling 150, as targeted by followers on Instagram it must be 2000.."

The target in this semester tends to decrease compared to the previous semester. In the beginning, the informant felt that the target of the business project was right. The fall in the target was inseparable from the obstacles faced in the previous semester, namely the informants were constrained by production problems. In addition, the informant had constraints on self-confidence, so he could not be maximal in offering products.

"...the constraints in production, the tailor can't be fast so we are in the third semester, we want a small target first but it can be achieved, then later if the target is reached the next semester the target is increased..." people..."

"... yeah I'm the type of shy person, the first time I went to college I didn't speak to other

To reach the target, the informant made sales through social media and consigned to a clothing store. The informant himself was optimistic he was able to reach the target, one of his motivations was to compete with former teammates who were now running a business in the same field. 
According to the informant, the target has positive and negative sides. Although initially forced but with such compulsion, the informant felt that there was a change in behavior, such as not delaying work and being more observant about opportunities. Informants felt that sometimes the facilitator did not understand the situation of the informant and was not maximal in providing business guidance.

The sixth informant is a 2013 business student project in the field of Javanese sugar trading which has a target to increase turnover of this semester compared to the previous semester. Following is the sixth informant's statement:

"The target is to increase turnover this semester... I mean if I can supply it to the soy sauce factory, or to big tenders, you know, but I don't have it yet..."

According to the Informant, the target of a business project is too much so that the person has difficulty dividing the time between business projects, lectures, and other activities. Informants also experience obstacles in terms of communicating with group members, often differences of opinion occur due to inequality in principle. In fact, there are some issues that cannot be resolved.

"Too much, I mean like we, for example, focus on work like this, yeah, maybe it's possible, but the focus isn't just this and the time is not enough, only a week has been used to study, go to church, and not include other activities... "

Suppliers and prospective customers also become obstacles for informants. Suppliers owned by informants are only one and have limited capital, so if the informant orders products in large quantities then the informant must provide capital first, while consumers pay after the product is received. Trust issues become obstacles to prospective customers. Often transactions only occur via telephone without face to face, this makes the informant worried about being deceived.

"... My supplier has a problem too, so he doesn't have too much money, you know, make a transaction, so we have to pay him quickly because he doesn't have money to use first..."

"... the term is not trusting, it's really like big money and I don't know it and like I don't believe it, because I can't meet in person, I'm not talking directly just by phone, so I'm afraid..."

The informant had a strategy while undergoing a business project, namely at the beginning of the semester the informant submitted a proposal for a product offer to various places, during the middle of the semester the food informant asked for feedback, when approaching the end of the semester the informant made a deal. This is done because if the deal is done at the beginning or middle of the semester, the informant will get another target / the target will increase.

\section{DISCUSSION OF RESULTS}

Based on the analysis of the data described earlier, it appears that there are various kinds of expressions and emotions that appear to informants, such as enthusiasm, confidence, doubt, sadness, anxiety, satisfaction, and pride. Observation carried out together with the interview is quite important, the purpose is to confirm the information conveyed by the informant is truly experienced and felt, not just words from the lips.

Each informant also experienced its own problems when running a student business project. Constraints faced include: product innovation that makes it difficult to compete with competitors, networks that are not broad are obstacles to getting the right suppliers and markets, lack of time to sell products because they are focused on product improvement, difficulty in finding product designs that right because of the diverse tastes of consumers, products that are still relatively new so that they are not widely known to the public, problems in self-esteem that prevent informants from offering products to prospective customers, unresolved disputes with group members, even informants who often target the facilitator very difficult to achieve, so that the target informant had not run it already feeling tired.

The researcher found that there were several similarities in the obstacles faced by informants. The first obstacle equation is with the supplier. Some student business projects 
have limited suppliers and some have only one supplier, so if the supplier cannot meet the needs of the business project, it will disrupt sales.

The informants also stated the difficulty in determining priorities and dividing the time between running business projects, participating in lecture activities, and carrying out activities outside the campus. This is because each student has responsibilities that must be implemented that sometimes clash with each other. Can be seen from the analysis of data that the target student business projects differ from each other, the authors see this difference in accordance with the conditions and abilities of the informant. When the writer asks about the target to the informants there are differences of opinion, some say the target is appropriate, the target is not appropriate, there are also informants who think it is better not to have a target because it is stressful and uncomfortable in running a business project even though the business it is running now is passion informant.

There were only a few informants who could explain well and be sure of their strategies to achieve the target for the next semester, and on the contrary many informants answered hesitantly when asked about their plans / strategies to reach the target. Researchers see, there are indications that informants do not have enough information about the types of strategies in the business field that the informant runs. Informants who seem doubtful about the strategy are indicative of doing activities that are not effective and efficient, there are even indications of carrying out activities or decisions that are wrong, in behavioral accounting theory these actions are called Escalation Commitments.

Some informants who seemed doubtful were not too concerned about the targets being achieved or not, the most important thing was that the informants had tried. That is, the informant considers that his fate is controlled or determined by the lecturer / environment, in behavioral accounting this kind of belief is called external locus of control, while the informant who looks confident in his strategy is optimistic that the strategies / plans that have been prepared with group members will be able to bring them to reach the target at the end of the semester, this belief in behavioral accounting is called internal locus of control. That is, there are informants who think that the value of business project courses is in the hands of lecturers and facilitators, but there are also informants who believe the value of business project courses is determined by the informant itself.

The difference in views that exist does not mean that there are informants who do not carry out any activities. Various activities have been carried out by informants so that business project targets are achieved, these activities include: starting from dividing tasks with group members, making activities schedules, going around offering products, to going out of town to expand networks of both suppliers and prospective customers. The author also found that there were informants who carried out budgetary slack actions, but interestingly the informant did not know that the actions taken were unethical. The informant thought the actions taken were part of the strategy to achieve the target.

The interesting thing is that even though there were differences of views regarding the target of each informant, all informants agreed that when running a business project a lot of experience was gained that influenced the Informant's behavior and way of thinking in a better direction, including: making informants more resilient. able to communicate better than before, can bring themselves, and the mindset of the entrepreneur in the informants is increasingly formed.

\section{CONCLUSION}

Based on the results of research conducted by researchers, the impact of business project targets on student behavior is the emergence of various kinds of reactions to the informants, some felt the target was right, there were those who felt the target was not right, there was also a feeling that there was no target. Some informants were able to explain well and be sure of their strategies to achieve the target for the next semester, there were indications that the informants believed that their fate / condition was determined by themselves so they seemed motivated to reach the target. 
Most of the other informants answered hesitantly when asked about plans / strategies to reach the target. It is possible that the informant did not have enough information about the types of strategies in the business field that the informant ran. The informant seemed to believe that his fate / situation was controlled by the environment, because it was indicated to carry out activities that were not effective and efficient so there was the possibility of committing an escalation commitment.

Various activities have been carried out by all informants to reach the target, including unethical actions that were not realized by the informants. All informants agreed with the target of making moves and increasingly moving to run and enlarge business projects, so that when running business projects there were many experiences gained by informants, those experiences that changed informants' behavior and ways of thinking in a better direction.

The target has a positive impact on the informants, even though the informants have different views on the target. Informants become more and more active in activities so that the target can be achieved, the number of these activities has a positive impact on informants in their entrepreneurial behavior and mindset. Target is not the main tool to motivate informants; the authors argue the main motivational tool is the maximum guidance process during business projects between lecturers and facilitators to the informants.

Based on the results of the research and discussion, the researcher realized that this research was not optimal, but was expected to be able to contribute scientific findings to the phenomenon that occurred. There are limitations in this study, the first being time constraints. The data collection and analysis phase takes a lot of time. The researcher realizes that carefulness is needed in conducting this research, because this research is very dependent on the judgment of the researcher. There are also limitations in understanding the data analysis process which is quite time-consuming because the researcher must find and study the appropriate analysis process in this study.

\section{REFERENCES}

1. Bambang S. dan Gugus I. 2011. Eskalasi dan De-Eskalasi Komitmen Pada Individu Yang Berkarakter Internal Locus of Control dalam Kasus Investasi Bertahap. Simposium Nasional Akuntansi XIV Aceh.

2. Blocher, S. C. 2010. Cost Management: A Strategic Emphasis. New York: McGraw-Hill Companies.

3. Bungin, B. 2014. Penelitian Kualitatif: Komunikasi, Ekonomi, Kebijakan Publik, dan IImu Sosial Lainnya. Jakarta: Kencana.

4. Cokroaminoto. 2011. Pendekatan Grounded Theory dalam Penelitian Kualitatif. Menulis Proposal Penelitian.

5. Damayanti, I. G., \& Wirasedana, I. W. 2014. Pengaruh Partisipasi Anggaran, Reputasi, Dan Etika Pada \Anggaran Pada Skpd Di Pemerintahan Kota Denpasar.

6. E-Jurnal Akuntansi Universitas Udayana, 133-142.

7. Donthu, N., \& Unal, B. 2014. Identifying escalation of commitment in B2B new product development projects using data envelopment analysis. Journal of Business \& Industrial Marketing, 209-214.

8. Ed Blocher, D. E. 2010. Manajemen Biaya: Penekanan Strategis. Jakarta Selatan: Penerbit Salemba Empat.

9. Efferin, Sujoko dkk. 2008. Metode Penelitian Akuntansi. Yogyakarta: Graha IImu

10. Emzir. 2010. Metodologi Penelitian Kualitatif: Analisis Data. Jakarta: PT.RajaGrafindo Persada

11. Kuswarno, Engkus. 2009. Metodologi Penelitian Komunikasi: Fenomenologi Konsepsi, Pedoman, dan Contoh Penelitiannya. Bandung: Widya Padjadjaran

12. Manaroinsong, J. 2014. Pengaruh Sistem Informasi Keuangan, Partisipasi Anggaran serta Sikap Perilaku Aparat terhadap Kinerja Keuangan Daerah di Provinsi Sulawesi Utara. Jurnal Aplikasi Manajemen (JAM), 373-384. 
13. Nahartyo, E. 2013. Budgetary Participation And Stretch Targets: Procedural Fairness In A Stretch Budget Condition. Ekuitas: Jurnal Ekonomi dan Keuangan, 33-47.

14. Pello, E. V. 2014. Pengaruh Asimetri Informasi Dan Locus Of Control Pada Hubungan Antara Penganggaran Partisipatif Dengan Senjangan Anggaran. E-Jurnal Akuntansi Universitas Udayana, 287-305.

15. Radianto, Wirawan. 2015. Akuntansi Keperilakuan: Memahami lebih dalam Eskalasi Komitmen. Surabaya: PT. Revka Petra Media.

16. Sugiyono. 2014. Memahami Penelitian Kualitatif. Bandung: Penerbit Alfabeta

17. Suwarni, E. 2012. Eskalasi Komitmen Individu Berdasarkan Locus Of Control Dalam Kasus Investasi. Ekuitas: Jurnal Ekonomi dan Keuangan, 430-450.

18. Tanjung, R. 2012. Strategi Pemberian Informasi Akuntansi Untuk Mengurangi Eskalasi Komitmen. Jurnal Ilmiah Mahasiswa Akuntansi, 22-27.

19. Widanaputra, A., \& Mimba, N. 2014. The influence of participative budgeting on budgetary slack in composing local governments' budget in Bali province. Procedia Social and Behavioral Sciences, 391-396. 